\title{
OPEM
}

www.opem.org

Oriental Pharmacy and Experimental Medicine 2008 8(3), 286-294

DOI 10.3742/OPEM.2008.8.3.286

\section{Investigation into the mechanism of anti-asthmatic action of Lepidium sativum}

\author{
BR Goyal $^{1,2}$, RK Goyal ${ }^{1}$ and Anita A Mehta ${ }^{1, *}$ \\ Department of Pharmacology, L.M. College of Pharmacy, Ahmedabad -380009, Gujarat, India; ${ }^{2}$ Institute of \\ Pharmacy, Nirma University of Science \& Technology, Ahmedabad 382481
}

Received for publication May 25, 2007; accepted November 21, 2007

\begin{abstract}
SUMMARY
We have studied the possible mechanism of anti-asthmatic action of ethanolic extracts of dried seeds of Lepidium sativum (EXLS, $400 \mathrm{mg} / \mathrm{kg}$ ) using various experimental models. EXLS produced an increase in the Pre-Convulsion Dyspnoea time induced by histamine and acetylcholine aerosol, a significant reduction in the elevated leucocyte counts in the BronchoAlveolar Lavage fluid of sensitized guinea-pigs and reduction in the paw edema volume as compared to the control rats. Treatment with EXLS also produced decrease in the elevated histamine release from the sensitized guinea-pig lungs. The anti-asthmatic anti-inflammatory responses of EXLS was supported by improvement in microscopic changes like infiltration of inflammatory cells, submucosal edema, epithelial desquamation and reduced lumen size of the bronchi. The $\mathrm{pD}_{2}$ values of histamine in tracheal chain and taenia-coli were significantly greater and that in lung strip was lower in the sensitized animals as compared to control. Treatment of sensitized guinea pigs with EXLS significantly decreased $\mathrm{pD}_{2}$ values of histamine in all three preparations. Our data suggest the prevention of hyper-responsiveness in bronchial smooth muscles and inhibition of the immediate hypersensitive reaction, histamine release in the lungs and the infiltration of various inflammatory cells as the possible mechanisms of anti-asthmatic activity of EXLS.
\end{abstract}

Key words: Lepidium sativum; Asthma; Histamine

\section{INTRODUCTION}

Lepidium sativum Linn. (EXLS) is used by many Ayurvedic practitioners for the treatment of bronchial asthma as it possesses 'Usna' virya (produces feeling of warmth). Also the use of EXLS seeds in hiccough is mentioned in Charak Samhita (An ayurvedic text). Further in the same text it is

\footnotetext{
*Correspondence: Anita A Mehta, Department of Pharmacology, L.M. College of Pharmacy, Ahmedabad - 380009, Gujarat, India. Tel: +917926302746; E-mail: dranitalmcp@rediffmail.com
}

also mentioned that both dyspnoea and hiccough should be managed identically due to their identical etiology, location and root. Our earlier data suggested that powdered dried seed kernels of EXLS showed marked decrease in commonly observed symptoms of bronchial asthma and significantly increased lung volumes (FVC, FEV 1 and MVV) and lung flow rates (PEFR and FEF 25 $75 \%$ ) in asthmatic patients (Marathe and Mehta, 2005). EXLS was also reported to cause dose dependent inhibition of contractions induced by various agonists viz. histamine, acetylcholine, 
5-Hydroxy Tryptamine (5-HT) and Barium chloride $\left(\mathrm{BaCl}_{2}\right)$ in guinea pig ileum which indicates its nonspecific spasmolytic activity on smooth muscles. It has shown mast cell stabilizing activity against Compound 48/80 and egg albumin induced mast cell degranulation and anti-inflammatory activity (Marathe and Mehta, 2003).

In the light of above mentioned facts, the objective of our present investigation was to further substantiate clinical data of the anti-asthmatic activity of EXLS by investigating the mechanism of action of EXLS using various experimental models.

\section{MATERIALS AND METHODS}

\section{Preparation of plant extracts}

Seeds of L. sativum were obtained, identified and authenticated by Department of Pharmacognosy, L. M. College of Pharmacy, Ahmedabad, India. Voucher specimens were deposited at the Dept. of Pharmacognosy, Ahmedabad. Dried seeds were powdered and used for the study.

The coarse powder $(500 \mathrm{~g}$ ) of the dried seed of L. sativum was defatted using petrol ether and then it was exhaustively extracted using 95\% ethanol $(2,000 \mathrm{ml})$ in a soxhlet extractor. The extract was concentrated under reduced pressure to yield a syrupy mass. This ethanolic extract of L. sativum was stored in airtight container in cool place and used throughout the project.

\section{Animals and drugs}

All animals were procured from Zydus Research Centre, Ahmedabad and housed at ambient temperature $\left(22 \pm 1^{\circ} \mathrm{C}\right)$, relative humidity $(55 \pm 5 \%)$ and $12 \mathrm{~h} / 12 \mathrm{~h}$ light dark cycle. Animals had free access to standard pellet diet and water given ad libitum. The protocol of the experiment was approved by the institutional animal ethical committee as per the guidance of the Committee for the Purpose of Control and Supervision of Experiments on Animals (CPCSEA), Ministry of Social Justice and Empowerment, Government of India (Protocol No.
09/2005 dated $5^{\text {th }}$ March, 2005). Weighed quantities of the extract of L. sativum was dissolved in distilled water to get the dose of $400 \mathrm{mg} / \mathrm{kg}$ and subjected to experimental study.

\section{Histamine and acetylcholine induced broncho- spasm in guinea pigs}

Guinea pigs of either sex weighing 350 - $500 \mathrm{~g}$ were kept in a closed chamber and exposed to an aerosol of $0.5 \%$ histamine hydrochloride and time for preconvulsion dyspnoea (PCD) was noted. After 15 days of wash out period the same animals were randomly divided into three groups each containing six animals. Group I received distilled water (Control); Group II and Group III received Ketotifen $(1 \mathrm{mg} / \mathrm{kg})$ or the EXLS $(500 \mathrm{mg} / \mathrm{kg})$ given as single dose two hours before the study. After two hours the animals were exposed to histamine aerosol and time for PCD was again noted. Similar procedure was repeated with the aerosol of $0.5 \%$ Ach in another three groups of animals.

\section{Passive paw anaphylaxis in rats (Martel and} Klicius, 1977)

Wistar rats of either sex were injected intraperitoneally with $0.2 \mathrm{ml}, 10 \%$ egg albumin and $0.2 \mathrm{ml}$ of Bordetella pertusis vaccine on day 1,3 and 5. Twenty-one days after the first immunization, blood was collected from orbital plexus under light ether anesthesia. The collected blood was allowed to clot and serum was seperated and given to another group of Wistar rats. They were randomly divided into three groups each containing six animals. Group I received distilled water (Control); Group II and Group III received Ketotifen (1 mg/ $\mathrm{kg})$ or EXLS $(500 \mathrm{mg} / \mathrm{kg})$ given orally in distilled water. Two hours after the last dose of drug administration (on seventh day), rats were passively sensitized in to the left hind paw with $0.1 \mathrm{ml}$ of the undiluted serum. The contra-lateral paw received an equal volume of saline. $24 \mathrm{~h}$ after sensitization, the rats were challenged in the left hind paw with $10 \mathrm{mg}$ of Egg albumin in $0.1 \mathrm{ml}$ saline. The hind paw 
volume was measured after $30 \mathrm{~min}$ by volume displacement method using mercury column plethysmometer.

\section{Broncho-alveolar lavage (BAL) fluid in guinea pigs (Thomas et al., 1995)}

Guinea pigs of either sex weighing 350 - $500 \mathrm{~g}$ were selected and randomly divided into four groups each containing six animals as mentioned before. The drugs were administered orally in distilled water. The guinea pigs of all the groups except group I were sensitized with egg albumin $(1 \mathrm{ml}$, $10 \% \mathrm{w} / \mathrm{v}$, i.p.). The animals of group III were dosed once daily for fifteen days with EXLS (500 $\mathrm{mg} / \mathrm{kg}$, p.o.). Two hours after the last dose of drug administration (on fifteenth day), all the animals except group I animals were challenged with egg albumin $(0.5 \mathrm{ml}, 2 \% \mathrm{w} / \mathrm{v})$ through saphenous vein. After $3 \mathrm{~h}$ of the challenge of the egg albumin or just prior to death of animals, whichever was earlier, the tracheobronchial tree was lavaged with $10 \mathrm{ml}$ of saline and the fluid so collected was centrifuged at 2,000 $\mathrm{rpm}$ for $5 \mathrm{~min}$. and the pellet was resuspended in $0.5 \mathrm{ml}$ saline. $0.2 \mathrm{ml}$ of Geimsa stain in buffered saline ( $\mathrm{pH}$ 6.8) was added to it. After $5 \mathrm{~min}$. the number of each type of leukocyte in $0.5 \mathrm{ml}$ fluid was determined under the microscope $450 \times$ magnifications.

Histamine release from lung tissues of guinea pigs Two times sensitization of guinea pigs with egg albumin as mentioned above for the BAL fluid studies was carried out. After $3 \mathrm{~h}$ of the challenge of the egg albumin or just prior to death of animals, the lungs of the guinea pigs were chopped into fragments. The chopped lung tissues were placed in tubes with $2 \mathrm{ml}$ of ice-cold $\mathrm{Ca}^{2+}$ free Tyrode's solution and kept on ice till further use. $200 \mathrm{mg}$ (wet weight) of lung tissues were taken in test tube. The test tubes were then supplemented with $1.8 \mathrm{mM} \mathrm{CaCl}{ }_{2}$ and incubated for $10 \mathrm{~min}$. at $37^{\circ} \mathrm{C}$. After that the lung tissues were incubated with $2 \mathrm{mg} / \mathrm{ml}$ egg albumin for $15 \mathrm{~min}$. at $37^{\circ} \mathrm{C}$. After
$15 \mathrm{~min}$, the reaction was stopped by filtration of the medium through nylon mesh $(100 \mathrm{~mm})$. Histamine in the medium was determined fluorometrically as described by Shore et al. (1959).

\section{Isolated tissue experiments}

Two times sensitization of guinea pigs with egg albumin as mentioned above for the BAL fluid studies was carried out. After $3 \mathrm{~h}$ of the challenge of the egg albumin the animals were sacrificed and various tissues were isolated and mounted in organ tubes filled with $20 \mathrm{ml}$ of the respective PSS and equilibrated under a uniform tension of 500 mg. The bathing solution was bubbled with $95 \%$ $\mathrm{O}_{2}$ and $5 \% \mathrm{CO}_{2}$ at $37 \pm 1{ }^{\circ} \mathrm{C}$.

The trachea was rapidly dissected free of surrounding tissues and tracheal chains were suspended in organ baths containing oxygenated Kreb's solution ( $\mathrm{NaCl}$ - $114.0 \mathrm{mM} ; \mathrm{CaCl}_{2}-2.5 \mathrm{mM}$; $\mathrm{KCl}$ - $4.7 \mathrm{mM}$; glucose - $11.7 \mathrm{mM} ; \mathrm{NaHCO}_{3}-25 \mathrm{mM}$; $\mathrm{MgCl}_{2}-1.2 \mathrm{mM} ; \mathrm{KH}_{2} \mathrm{PO}_{4}-1.2 \mathrm{mM}$ ). A piece of taenia coli about $4-5 \mathrm{~cm}$ in length was mounted in organ bath containing Tyrode solution $(\mathrm{NaCl}-137 \mathrm{mM}$; $\mathrm{CaCl}_{2}$ - $1.8 \mathrm{mM}$; $\mathrm{KCl}$ - $2.7 \mathrm{mM}$; glucose - $5.55 \mathrm{mM}$; $\left.\mathrm{NaHCO}_{3}-11.9 \mathrm{mM} ; \mathrm{MgCl}_{2}-1 \mathrm{mM} ; \mathrm{NaH}_{2} \mathrm{PO}_{4}-0.4 \mathrm{mM}\right)$. Lateral strip of subpleural parenchyma from the lower lobe of left lung was mounted in organ baths containing in modified Krebs-Henseleit $(\mathrm{KH})$ solution $\left(\mathrm{NaCl}\right.$ - $118.4 \mathrm{mM} ; \mathrm{CaCl}_{2}-2.5 \mathrm{mM} ; \mathrm{KCl}$ - $4.7 \mathrm{mM}$; glucose - $11.1 \mathrm{mM} ; \mathrm{NaHCO}_{3}-25.0 \mathrm{mM} ; \mathrm{MgSO}_{4}$ $0.6 \mathrm{mM} ; \mathrm{K}_{3} \mathrm{PO}_{4}-1.2 \mathrm{mM}$ ).

All the preparations were allowed to stabilize for $45 \mathrm{~min}$ and the PSS in organ bath was changed every $10 \mathrm{~min}$. The responses to histamine were recorded using student physiograph (Bio Devices) using isotonic transducer.

\section{Histopathological study}

Histopathological study of bronchi and bronchioles obtained from guinea-pigs was also carried out. Dissected lungs were washed with normal saline and then kept in $10 \%$ formal saline. The tissues were then kept in Bouin's fixative for 18 to $24 \mathrm{~h}$. 
Tissues were then washed twice with distilled water and kept in $70 \%$ alcohol. A pinch of lithium carbonate was added to remove excessive stain. The tissues were washed and kept in 70\% alcohol again. After that tissues were transferred to $90 \%$ alcohol and kept in it overnight. Next morning all tissues were transferred into $100 \%$ alcohol and kept for $3 \mathrm{~h}$. Then the tissues were transferred to xylene and kept till they become transparent. Tissues were fixed in melted paraffin in wooden blocks, so that sectioning can be performed. Several sections of $3 \mu \mathrm{m}$ thickness were taken from each tissue and sections with uniform shape and size were selected for histology. Selected sections were fixed on the clear glass slide with the help of egg albumin. Tissues were stained using Heamotoxyllin and Eosin (H \& E) stain.

\section{Statistical analysis}

Results are presented as mean \pm S.E.M. Statistical differences between the means of the various groups were evaluated using one-way analysis of variance followed by Tukey test. Data were considered statistically significant at different $P$-values.

\section{RESULTS}

Effect of EXLS on histamine and acetylcholine induced bronchospasm in guinea pigs

Pretreatment of the guinea pigs with ketotifen, the standard drug and EXLS $2 \mathrm{~h}$ before the aerosol significantly increased PCD time. The \% increase in PCD time by EXLS $(86.4 \pm 1.8)$ was significantly
$(P<0.001)$ higher as compared to the ketotifen $(28.8 \pm 2.7)$ when bronchospasm was induced by histamine. However, when acetylcholine was used to induce bronchospasm, the increase in preconvulsion dyspnoea time by EXLS $(29.4 \pm 1.6)$ was not significantly different from ketotifen $(33.9 \pm 3.1)$.

Effect of EXLS on passive paw anaphylaxis in rats The treatment with the standard drug ketotifen produced significantly $(P<0.001)$ less edema $(8.04$ $\pm 1.1 \%)$ as compared to the control animals (38.4 \pm $0.649 \%)$. The treatment EXLS also produced significantly $(P<0.001)$ less edema $(19.96 \pm 0.78 \%)$ as compared to the control animals. Thus, ketotifen and EXLS produced $79.07 \%$ and $48.03 \%$ inhibition of edema at $30 \mathrm{~min}$ respectively.

Effect of EXLS on differential leucocyte counts of the BAL fluid in egg albumin sensitized guinea pigs A highly significant increase in the total leucocyte count, eosinophil monocyte, neutrophil and lymphocyte counts were observed in the sensitized animals as compared to control animals. The treatment with EXLS produced a significant decrease in these elevated counts as compared to sensitized animals (Table 1).

Effect of EXLS on antigen induced histamine release from lung tissue of guinea pigs

The treatment with EXLS produced a highly significant decrease $(53.6 \pm 0.9 \mu \mathrm{g} / \mathrm{g})$ in the elevated histamine release as compared to sensitized animals $(186.7 \pm 3.8 \mu \mathrm{g} / \mathrm{g})$.

Table 1. Effect of Lepidium sativum on change in differential leucocyte counts of the Broncho-Alveolar-Lavage (BAL) fluid

\begin{tabular}{lccc}
\hline & Control & Sensitized (SEN) & SEN + EXLS (500 mg/kg) \\
\hline Total Leucocyte Count & $5,625 \pm 822.98$ & $16,300 \pm 1,077^{*}$ & $10,167 \pm 1,752.5^{@}$ \\
Eosinophil Count & $96.5 \pm 33.36$ & $578.8 \pm 46.98^{*}$ & $241.5 \pm 61.27^{\circledR}$ \\
Monocyte Count & $102 \pm 24$ & $776 \pm 144.77^{*}$ & $241.5 \pm 61.27^{\circledR}$ \\
Neutrophil Count & $1,764.7 \pm 249.4$ & $5,803.8 \pm 340.61^{*}$ & $3,242.7 \pm 601.67^{\circledR}$ \\
Lymphocyte Count & $2,844.3 \pm 471.1$ & $10,504 \pm 256.35^{*}$ & $7,134 \pm 470.42^{@}$ \\
\hline
\end{tabular}

Values are in mean \pm S.E.M. $\left(n=6\right.$ in each group). ${ }^{*}$ Significantly different from control $(P<0.001) ;{ }^{\circledR}$ Significantly different from sensitized $(P<0.05)$. 


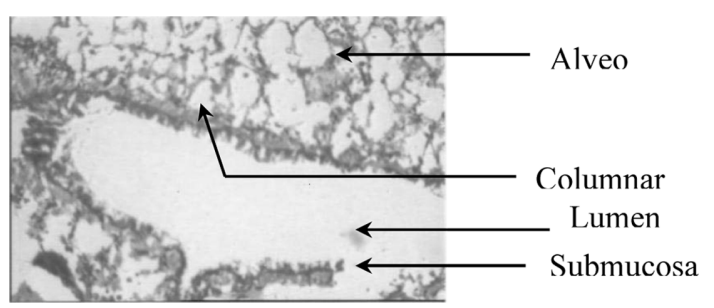

Fig. 1. Normal. Representative figure of the section of lungs from normal guinea-pigs. Magnification $\times 40$.

\section{Histopathological alterations and effect of EXLS} on bronchioles in guinea pigs

Microscopically non sensitized control guinea pigs showed no pathological changes in the lung and bronchioles (Fig. 1). Histological examination of the sections of lungs from untreated sensitized guinea pigs (Fig. 2) showed marked microscopic changes like infiltration of inflammatory cells leucocytes, submucosal edema and epithelial desquamation. The lumen size was reduced

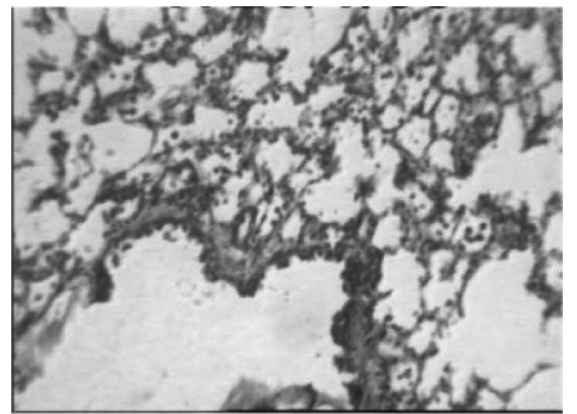

Fig. 3. Sensitized + EXLS. Representative figure of the section of lungs from sensitized guinea-pigs treated with EXLS. Magnification $\times 40$.

drastically. The infiltration of the inflammatory cells was comparatively less in the lung sections of the sensitized animals treated with EXLS (Fig. 3). There was less submucosal edema and less epithelial desquamation in these sections. The lumen size was also normal.

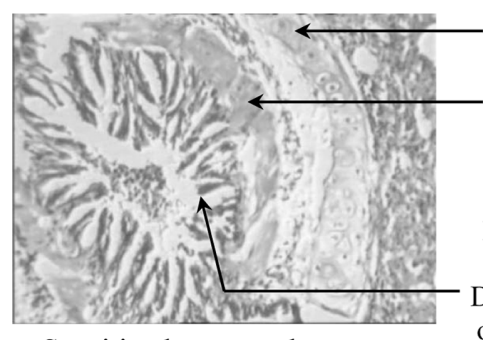

a. Sensitized untreated.

Leucocyte

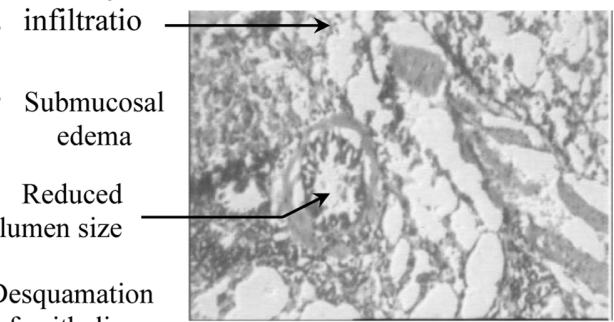

of epithelium

b. Sensitized untreated.

Fig. 2. Representative figure of the section of lungs from sensitized untreated guinea-pigs. Magnification $\times 40$.

Table 2. Effect of Lepidium sativum and Lepidium sativum on the $\mathrm{pD}_{2}$ value of Histamine and Acetylcholine in various isolated tissue preparations of guinea pig

\begin{tabular}{lcc}
\hline Preparation & Treatment & $\mathrm{pD}_{2}$ of Histamine \\
\hline \multirow{2}{*}{ Guinea pig Tracheal Chain } & Control & $6.24 \pm 0.025$ \\
& Sensitized (SEN) & $6.54 \pm 0.07^{*}$ \\
& SEN + EXLS (500 mg/kg) & $5.15 \pm 0.04^{* * * @ @ ~}$ \\
Guinea pig Taenia Coli & Control & $6.66 \pm 0.14$ \\
& Sensitized (SEN) & $6.85 \pm 0.053$ \\
& SEN + EXLS (500 mg/kg) & $6.62 \pm 0.012^{@}$ \\
Guinea pig Lung Strip & Control & $5.89 \pm 0.004$ \\
& Sensitized (SEN) & $5.64 \pm 0.002^{* * *}$ \\
\hline
\end{tabular}

${ }^{{ }^{\circ}} P<0.01,{ }^{* * *} P<0.001$, significantly different from control. ${ }^{@} P<0.05,{ }^{@ @} P<0.001$, significantly different from sensitized. 
Effect of EXLS on histamine induced contractions on various isolated tissue preparations of guinea pigs Histamine produced dose dependent contraction of various isolated tissue preparations of guinea pigs viz. tracheal chain, taenia coli and lung strip. The $\mathrm{pD}_{2}$ values of histamine obtained in tracheal chain and taenia coli were significantly greater than those obtained from the control animals. In guinea pig lung strip, there was a decrease in $\mathrm{pD}_{2}$ values to histamine obtained from egg albumin induced sensitized animals as compared to the control animals (Table 2). Treatment of egg albumin sensitized guinea pigs with EXLS produced a significant decrease in $\mathrm{pD}_{2}$ value of histamine in all these preparations (Table 2).

\section{DISCUSSION}

In the initial stage of asthma, exposure to allergens and irritants like pollens, moulds, house dust mites, animals' dander, occupational chemicals cause activation of inflammatory cells. These cells can synthesize and secrete a vast numbers of mediators like histamine, trypase, leukotrienes and prostaglandins that cause bronchoconstriction, submucosal gland secretion and vasodilation resulting in the early phase asthmatic response. So in the present study histamine and Ach were used as spamogens in form of aerosols to cause immediate bronchoconstriction in guinea pigs. Bronchodilating effects of EXLS were thus evaluated by observing the effects of their ethanolic extracts on PCD time. EXLS was found to significantly increase the PCD time against histamine and Ach aerosol as compared to control animals indicating their bronchodilating activity and further substantiating the previous laboratory data.

Asthma has been described primarily as an inflammatory process in the last one decade. The inflammatory process is now considered to be an immunologically initiated, mediator-driven event. The three main components of the immune system are antibodies, inflammatory cells, and inflammatory mediators. The antibody involved in allergic asthma, is the immunoglobulin IgE (Murray and Nadel, 2000). The passive paw anaphylaxis model involves passive immunization with serum containing $\operatorname{IgE}$ antibodies and then second antigen being egg albumin which causes immediate hypersensitivity reaction in form of paw edema. In the present study, the paw edema was significantly inhibited by EXLS. This suggests that EXLS possess anti allergic activity.

Exposure of actively sensitized guinea pigs to allergens results in selective pulmonary eosinophilia, a response that has been associated with airway hyperreactivity (Sanjar et al., 1990a; Santing et al., 1994). When activated, eosinophils release several pre-formed mediators from within their granules. These granules contain several proteins like eosinophilic cationic protein, eosinophil-derived neurotoxin, peroxidase, and cationic protein. Major basic protein, in particular, can directly damage airway epithelium, intensify bronchial responsiveness, and cause degranulation of basophils and mast cells which increase the severity of asthma. Eosinophils release inflammatory mediators such as leukotrienes, particularly the cysteinyl leukotriene $\mathrm{C}_{4}$, which contracts airway smooth muscle, increases vascular permeability, and may recruit more eosinophils to the airways (Rothenberg, 1998). In the present study it was found that alcoholic extract of EXLS did not significantly reduce the total leucocyte counts, neutrophil and lymphocyte counts but selectively reduced the eosinophil and monocyte counts thereby preventing the direct damage of airway epithelium. This supports the previous data that EXLS showed mast cell stabilizing activity against Compound $48 / 80$ and egg albumin induced mast cell degranulation (Marathe and Mehta, 2003). This effect of EXLS is comparable to that of Boswellia serrata which blocks the synthesis of pro-inflammatory 5-lipoxygenase products, including leukotriene $\mathrm{B}_{4}$ (Ammon et al., 1991).

The immunologic cascade and the ensuing 
inflammatory reaction comprise activation of specific inflammatory cells that also release various inflammatory mediators, such as histamine, mast cell tryptase, leukotrienes, prostaglandins, eosinophil cationic protein, and cytokines. Acute release of histamine following an allergic or non-allergic insult may lead to bronchoconstriction, which can be attenuated by selective $\mathrm{H}_{1}$-receptor antagonists (Holgate and Finnerty, 1989). There is evidence that histamine may also stimulate sensitized afferent nerves (Empey et al., 1976). With regard to inflammatory cells, histamine has been shown to activate eosinophils (Raible et al., 1994). Thus estimation of histamine levels in the lung tissue itself reveals the mediator release. In the present investigation, the histamine levels, which are increased due to sensitization with egg albumin, were found to be near to normal levels in the EXLS treated animals. This depicts that EXLS inhibit the release of the inflammatory mediator - histamine. From the ongoing discussion, it can be concluded that EXLS affect all the three components of immunity and inflammation involved in bronchial asthma. This is comparable to that of Tylophora asthmatica which acts by affecting cell-mediated immunity (Haranath and Shyamalakumari, 1975). In asthma, there occurs chronic inflammation, which then leads to bronchoconstriction and decrease in the lumen size of the bronchioles. In the present study, the sections of the animals sensitized with egg albumin depicted marked bronchitis and severe bronchoconstriction. Treatment with EXLS prevented this inflammation and bronchoconstriction. This further suggests that it prevents the inflammation of bronchi and bronchioles and hence prevent the bronchoconstriction. This may thus lead to normal lumen size and normal lung function in the asthmatic patients.

Asthma is characterized by increased mucus production and airway hyper-responsiveness resulting in decreased airflow, and marked by recurrent episodes of wheezing, coughing, and shortness of breath. The presence of histamine $\mathrm{H}_{1}$ sensitive excitatory receptors in airway smooth muscle of man and animals has been reported (Chand and Eyre, 1975; Fleisch and Calkains, 1976; Persson and Ekamn, 1976). Presence of Histaminergic $\mathrm{H}_{1}$ and $\mathrm{H}_{2}$ excitatory receptors are reported in the guinea pig taenia coli (Patel et al., 1980). In the present study it was found that there occurs an increase in $\mathrm{pD}_{2}$ value of histamine in the guinea pig tracheal chain and taenia coli preparations obtained from animals sensitized with egg albumin indicating the hyperresponsiveness to the histamine. The treatment with EXLS decreased the $\mathrm{pD}_{2}$ value to histamine indicating that it prevented the hyperresponsiveness to histamine and thereby produces protective effects in bronchial asthma. Unlike tracheal chain and taenia coli preparations, in the lung strips obtained from animals sensitized with egg albumin, decrease in responses to histamine was observed. This can be attributed to the fact that, increase in the levels of a mediator may cause desensitization of the receptors. Hollenberg (1985a) reported that prolonged exposure of biological systems to high concentrations of stimulating agents often leads to the development of negative feedback response and desensitization. Histamine induced desensitization of $\mathrm{H}_{1}$ receptor has been documented in various isolated cell systems (Baenzinger et al., 1981; Nakhata and Harden, 1987; McDonough et al., 1988) and smooth muscle preparations (Anderson et al., 1979), which may be due to alteration of histamine levels at the receptor site (Horio et al., 1990). In the present study, the histamine levels in the lungs of these animals were found to be increased and thus there might be desensitization of the histaminergic receptors in the lung tissue of the animals sensitized with egg albumin. The treatment with EXLS caused decrease $\mathrm{pD}_{2}$ value of the histamine in the lung strip. This can be explained on the fact that histamine levels in these animals are significantly less as compared to sensitized animals. It is possible that since in the lung strip preparations obtained from animals treated with these drugs, the histamine levels are 
not increased as compared to control animals, the desensitization of the receptors might not have occurred. The decrease in $\mathrm{pD}_{2}$ value of histamine observed in the lung strip might be due to the overall decrease in hyperresponsiveness by the treatment. As mentioned above, the treatment with EXLS was found to cause decrease in $\mathrm{pD}_{2}$ value of histamine in tracheal chain and taenia coli preparations also. Further it is reported that the intestinal mucosa, lungs and skin are particularly rich source of histamine (Feldberg, 1956). It can be assumed that there is no desensitization occurring in the tracheal chain or taenia coli because these tissues are not rich in mast cells and hence the histamine levels are not significantly altered in these tissues.

In conclusion our data suggest that EXLS possess significant anti-asthmatic activity and may be useful in treatment both - acute and chronic phases of extrinsic asthma. The possible mechanism of anti-asthmatic activity of EXLS appears to be not only prevention of hyperresponsivess in bronchial smooth muscles but also inhibition of the immediate hypersensitive reaction provoked by an allergen, inhibition of the infiltration of various inflammatory cells and inhibition of histamine release in the lung tissue.

\section{ACKNOWLEDGEMENTS}

We wish to acknowledge Gujarat Council on Science and Technology (GUJCOST) for the financial support.

\section{REFERENCES}

Ammon HP, Mack T, Singh GB, Safayhi H. (1991) Inhibition of leukotriene $\mathrm{B}_{4}$ formation in rat peritoneal neutrophils by an ethanolic extract of the gum resin exudates of Boswellia serrata. Planta med. 57, 203-207.

Baezinger LN, Fogerty FJ, Mertz LF, Chernuata LF. (1981) Regulation of histamine mediated prostacyclin synthesis in cultured human vascular endothelial cells. Cell 24, 915-923.

Chand N, Eyre P. (1975) Classification and biological distribution of histamine receptor subtypes. Agents Actions 5, 277.

Empey DW, Laitinen LA, Jacobs L, Gold WM, Nadel JA. (1976) Mechanisms of bronchial hyperreactivity in normal subjects after upper respiratory tract infection. Am. Rev. Respir. Dis. 113, 131-139.

Feldberg W. (1956) Distribution of histamine in the body. In: Wolstenhulme GEW and O'Connor CE eds. Ciba Foundation, Symposium on histamine. Little Brown and Co. 4-13.

Fleisch JH, Calkins PJ. (1976) Comparison of druginduced responses of rabbit trachea and bronchi. $J$. Appl. Physiol. 41, 62.

Haranath PSRK, Shyamalakumari S. (1975) Experimental study on the mode of action of Tylophora asthmatica in bronchial asthma. Indian J. Med. Res. 63, 661-670.

Holgate ST, Finnerty JP. (1989) Anti-histammines in asthma. J. Allergy Clin. Immunol. 83, 537-47.

Hollenberg MD. (1985) Examples of homospecific and heterospecific receptor regulation. Trends Pharmacol. Sci. 6, 242-245.

Horio S, Shima m, Ueda H, Ishida Y. (1990) Temperature dependence of desensitization induced by acetylcholine and histamine in guinea-pig ileal longitudinal muscle. Br. J. Pharmacol. 100, 636-640.

Marathe A, Mehta AA. (2003) Lepidium sativum seeds in bronchial asthama. Indian J. Pharmacol. 33, 143-144.

Martel RR, Klicius JJ. (1977) Reagin-mediated hypersensitivity reaction in the rat hindpaw and its inhibition by antianaphylactic drugs. Int. Arch. Allergy Appl. Immunol. 54, 205-209.

Murray JF, Nadel JA. (2000) Textbook of Respiratory Medicine. Vol. 1, 3rd ed. Philadelphia, Pa.: W.B. Saunders.

Patel NM, Goyal RK, Verma SC. (1980) Histaminergic $\mathrm{H}_{1}$ and $\mathrm{H}_{2}$ excitatory receptors in the guinea pig uterus and taenia coli. Can. J. Physiol. Pharmacol. 58, 1500-1503.

Persson Cag, Ekamn M. (1976) Contractile effects of histamine in large and small respiratory airways. Agents Actions 6, 389.

Raible DG, Lenahan T, Fayvilevich Y, Kosinski R, Schulman ES. (1994) Pharmacologic characterization of a novel histamine receptor on human eosinophils. Am. J. Respir. Crit. Care Med. 149, 1506-1511. 
Rothenberg ME. (1998) Eosinophilia. N. Engl. J. Med. 338, 1592-1600.

Sanjar S, Aoki S, Boubkeur K, Chapman ID, Smith D, Kings MA, Morley J. (1990) Eosinophil accumulation in pulmonary airways of guinea-pigs induced by exposure to an aerosol of platelet-activating factor: effect of anti-asthma drugs. Br. J. Pharmacol. 99, 267272.

Santing Re, Olymulder CG, Zaagsma J, Meurs H. (1994) Relationships among allergen induced early and late phase airway obstructions, bronchial hyperactivity and inflammation in conscious, unrestrained guineapigs. J. Allergy Clin. Immunol.
93, 1021-1030.

Sheth UK, Dadkar Nk, Kamat NG. (1972) Selected topics in experimental pharmacology. Kothari book depot, Bombay, 5, 63.

Shore PA, Burkhalter A, Cohn VH. (1959) A method for the fluorometric assay of histamine in tissues. J. Pharmacol. Exp. Ther. 127, 182-186.

Thomas G, Aroajo CC, Agra F. (1995) Preliminary studies on the hydroalcoholic extract of the root of Cissampelos sympodialis Eichl in guineapig tracheal strip and bronchoulveolar leucocytes. Phytother. Res. 9, 473-477. 